\title{
Fashion and Lifestyle: Islamic Branding Using Vlog Activities on the Sungkars Family YouTube Channel
}

\author{
N Adhha ${ }^{1}$ \\ Graduate School of Syarif Hidayatullah State Islamic University of Jakarta, Indonesia ${ }^{1}$ \\ \{nurul.adhha13@mhs.uinjkt.ac.id ${ }^{1}$ \}
}

\begin{abstract}
Indonesia possesses various kinds of YouTube channels that become one of the popular social media in social life. It is used to be a communication activities platform through cyberspace by uploading videos informing diverse content. One of the existed YouTube channels nowadays is The Sungkars Family. Furthermore, it does not only provide the ordinary daily vlog activities, but it also presents a friendly content about education and missionary endeavor (da'wah). Through the videos, it can be one of the YouTube channels which promote Islamic branding based on lifestyles and fashions. What is more, this research is aimed to describe how the video activities model on The Sungkars Family YouTube channel introduces Islamic branding through their daily activities' vlog. As a result, the author seems to analyze the represented values of fashion and lifestyle as well as those types used in The Sungkars Family YouTube channel in attracting the attention of young audiences on each video. In addition, the theory utilized as the reference in the research is Branston and Stafford's theory about representation in news, including pictures, writings, stories, and a current situation. Also, it is about the concept of media representation which is able to present the construction of repeated presentations from real life. The representation can be such a reflection of reality through several images related to the conclusion of what to be displayed. Moreover, social media becomes a media that enable people to represent themselves in a digital form to the other people for the intended objectives. Specifically, this research is included in a qualitative research methodology by using content analysis and virtual ethnography on The Sungkars Family YouTube channel. In the research, the author acts as the subscriber to observe, reconstruct the dialogues, describe, and document the information and activities virtually. Then, the results of the analysis explained descriptively. By using the representative concept, the author would like to appear how the admin of The Sungkars Family YouTube channel uses the activities-based various daily videos. Further on, the usual content providing on its YouTube channel is about family lifestyle and fashion. Through those contents, the admin can show the Islamic branding actively and the illustration of Islamic youths in Indonesia through the channel.
\end{abstract}

Keywords: Representation, Social Media, YouTube Channel, The Sungkars Family 


\section{Introduction}

The use of social media, such as Instagram, WhatsApp, Line, Facebook, and YouTubehas been increased in these several years and most of the Indonesian millennials are familiar with all of the social media mentioned [1]. Specifically, the millennial generation refers to the generation who were born between 1980 and 1995. Furthermore, Pew Research Center (2017) has identified that the millennial generation has unique characters. For instance, all of them are connected by social media, burdened by debts, distrust of people, in no hurry to get married, and optimistic about the future. Based on the data gathered from the Indonesian Central Statistics Agency, the numbers of millennials are dominated by the productive population, which reaches up to $50 \%$ in 2017 and $70 \%$ from the labor potential in 2020 until 2030. What is more, Indonesia was ranked in the eighth position among the global internet users in 2015, besides China, India, IS, Brazil, Japan, Russia, and Nigeria. Whereas, the penetration rate of the users' percentage per total population was only $28.2 \%$ slightly higher than Bangladesh or Mongolia [2]. Moreover, internet usage in Indonesia had expanded dramatically, with an increase of 3,550 percent between 2000 and 2015. In addition, more than 84 percent of Indonesians were the third-largest Instagram users in the world after Brazil and USA in 2017 and was considered as the biggest Instagram community in the Asia Pacific [3]. In fact, Instagram becomes the most popular platform and social media for the millennial generation because of the simplicity, efficiency, and availability of the interesting features, such as Insta story that can be used to share many things instantly.

Also, one of the popular social media nowadays in the world and in Indonesia is YouTube, which provides all of the uploaded videos and can be watched and downloaded by many people [4]. Besides, it can be a strategic media to publish various information and news that obtains the increasing viewers in every second. The Pew Research Center (2017) reported that more than 1 billion unique users in the world visit YouTube every month [5]. In addition, there was fifty-one percent of adults watching videos on YouTube and approximately ten percent of them were the news viewers. This statistic rate seems impressive because basically, the target audiences are youths. Thus, nine out of ten youths aged eighteen to twenty-nine years old have watched online videos and almost 48 percent of them also watch online news on YouTube. Therefore, the news agency can facilitate YouTubers as a platform for publishing news and information.

It can be said that the existence of social media offers a new opportunity for many people to share information easily over time. Nowadays, social media do not only have a new space to share information, but it also creates a unique culture to develop in cyberspace. Fisher (2012) stated that the great potential of social media can be divided into three parts, such as production, consumption, and marketing [6]. These three things are considered binding the people when they use social media. For instance, the audiences have the power to organize what the information needed and what should be disseminated. Moreover, the power of social media can create a space for the content creators to promote themselves. Also, its strength has attracted many people from different levels and status to articulate their identities and spread the ideas including religious messages.

Notably, the mass media also has been developed very fast since the development of communication technology. Moreover, mass communication is more sophisticated and complex and possesses more power than the previous period. It is indicated by a new media which can be faster than the conventional mass media. In this research, the term of new media is related to the internet, which has been used since the 1960s and completed by various applied communication technology. Denis Mc Quail (2011) argued that the main 
characteristics of the new media are their relationship and easier access to societies. What is more, it provided a community and comport zone in communication [7]. Castell (2007) explained that communication technology can create a vast space for users to communicate and power on the information [8].

Based on the data gathered from the Association of Internet Service Providers Indonesia in 2016, 31.3 million people in Indonesia had used the internet to access information and around 54.4 million Indonesians utilized the Internet to watch a film. In addition, it was stated that YouTube was ranked as the third position of the social media category that as frequently visited. Moreover, 14.5 million people in Indonesia had accessed YouTube pages throughout 2016. It can be said that the rise of the internet has contributed to the changes in the communication form [9].

In light of Gehl (2009) indicated that YouTube seems to become a new form of a technique of communication. It represents itself through the video uploaded on its channel. Further on, YouTube also can be classified into a digital archive that is able to access it every time [11]. an assessor of media and communication defined that YouTube is being more than a service provider in the form of video content because the content produced can be saved by other people [12]. On the other hand, the content created for uploading on YouTube channel can become recycled from the first source of mass media. Based on the argument that has been explained, the author would like to emphasize the potential of YouTube which is not only created as a place for digital communication, but it also can be a productive platform for youths to produce various creative ideas.

Currently, YouTube has become one of the social media used by the millennial generation which is able to create a forum for communication through cyberspace in encouraging creative religious ideas in societies by daily vlog. One of the existed YouTube channels nowadays is the SungkarsFamily which does not only provide the daily video activities, but it also contains the educational content and the Islamic values that are easy to understand and implement in our life. Through the video, the Sungkars Family can be a pioneer to promote the Islamic values by their videos of Islamic lifestyles and fashion.

In accordance with the explanations above, this research is aimed to describe how the videos of The Sungkars Family can promote Islam to the public. By analyzing the content in the YouTube channel of The Sungkars Family, the author would like to investigate the creation types used by the content creators whether in the form of pictures, writing, stories, and the current situation of the Muslims' lifestyle and fashion in Indonesia. As a result, the analysis of the research will contain information about the construction of Islamic values displayed by The Sungkars FamilyYouTube Channel through the concept of media representation. Specifically, this research also will focus on investigating the da'wa concept, presented in The Sungkars Family YouTube Channel that can represent itself as one of the role models of Muslims in Indonesia in the digital form to the public.

\section{Method}

This research is included in a qualitative research methodology by using content analysis and virtual ethnography on the YouTube channel of The Sungkars Family. Hine (2000) stated that the content analysis and the virtual ethnography are categorized to good methods in observing the online interaction [13]. Furthermore, ethnography can be defined as a qualitative research methodology in which investigates and describes in-depth about humans' life and their daily activities. In addition, it is aimed to provide access to the researchers to know more about the key informant through their own way [14]. Moreover, the virtual 
ethnography was presented to analyze the dynamics of a virtual community, which has emerged as a new tool in analyzing the dynamics of the virtual community. What is more, to collect the data of the research, the author utilized online observation, online interviews, capturing logs, screen shows, videos, and audios. The theory utilized as the reference in the research is Branston and Stafford's theory about representation in a news, including pictures, writings, stories, and a current situation. Also, it is about the concept of media representation which is able to present the construction of repeated presentations from real life. The representation can be such a reflection of reality through several images related to the conclusion of what to be displayed. Moreover, social media becomes a media that enable people to represent themselves in a digital form to the other people for the intended objectives. After surveying several Vlogs on YouTube channel, the author decided to choose The Sungkars FamilyYouTube Channel. In the research, the author acts as the subscriber to observe, reconstruct the dialogues, describe, and document the information and activities virtually. Besides, the author also involved one of the subscribers of The Sungkars FamilyYouTube Channel to explore the research. Then, the results of the analysis explained descriptively.

\section{Result and Discussion}

\section{A. The Uniqueness Points of The Sungkars Family YouTube Channel}

The YouTube channel of The Sungkars Family is one of the popular YouTube channels in the millennial generation. It is introduced by two Sungkar's families, including ShireenSungkar and her husband, TeukuWisnu and his children named Cut Hawwa Medina Alfatih and Cut Shafiyyah Mecca Alfatih. Another member of The Sungkars Familyis Zaskia Sungkar and her husband named Irwansyah. Currently, The Sungkars FamilyYouTube Channel has uploaded 127 videos containing various themes and contents and all of them have been watched for about 159,058,036 times with 2,291,814 million subscribers [15]. Moreover, it was registered on YouTube for the first time on April 21st, 2018.

Meanwhile, The Sungkars FamilyYouTube Channel has diverse preferences about the type of content to be uploaded. Their preferences in uploading videos are aimed to entertain people, share experiences related to the Islamic values, show harmony in a family, share any information about tourist attractions and culinary, as well as information about education and business. Also, they include entertainment content by delivering Islamic values with funny approaches. Through different methods in conveying the message of communication, other people may obtain moral values as a form of Islamic branding. As shown in Figure 3.1, the text on the highlight video which is stated "Masyaa Allah, Paula is wearing a hijab, so Baim becomes fascinated". It contains a moral value to be more religious supported by the funny cover videos. The combination of images and writing on the videos is able to represent that the character in the video has a good intention to be a religious wife. The Sungkars FamilyYouTube Channel is being the Islamic channel that has shared about the Islamic knowledge, particularly about lifestyle and fashion. Because of the unique contents, many teenagers like watching the videos provided by The Sungkars Family. For instance, sharing about their holiday experiences at overseas by wearing religious outfits and also Islamic fashion exhibition held in some countries. Specifically, they provide simple tutorial videos about how to wear hijab and outfits for women. For example, the tutorial video entitled "Rectangular Hijab Tutorial for Covering Chest by Shireen" has reached the fifth rank with 3.3 million viewers as the most popular video on their channel. 


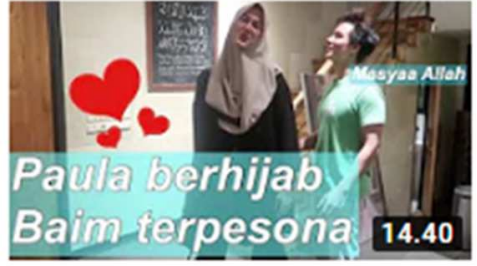

BONGKAR LEMARI ARTES ,bapauu \#03

$3,4 \mathrm{jtx}$ ditonton .

5 bulan yang lalu

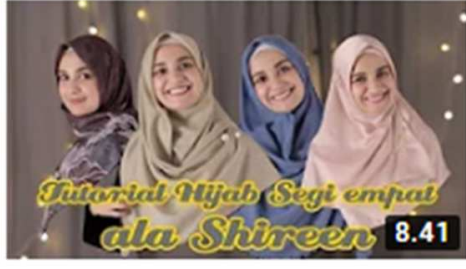

Tutorial hijab segi empat menutup dada ala Shireen

\section{3,3 jtx ditonton .}

6 bulan yang lalu

Figure 3.1 The Fourth and the Fifth Popular Videos

Another video uploaded on The Sungkars FamilyYouTube Channel is about the Q\&A session, which conveys the Islamic messages through storytelling method and answering the question from the viewers. The videos about Q\&A session are captured on figure 3.2

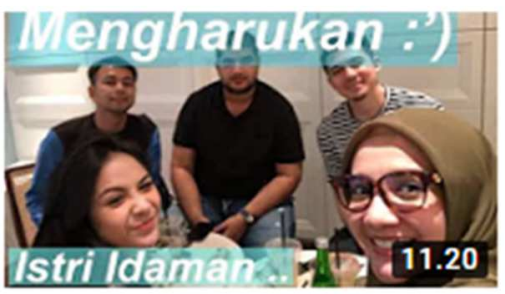

Gigi malah Suka DIMARAHIN Raffi , alesannya...

1,4 jtx ditonton -

5 bulan yang lalu

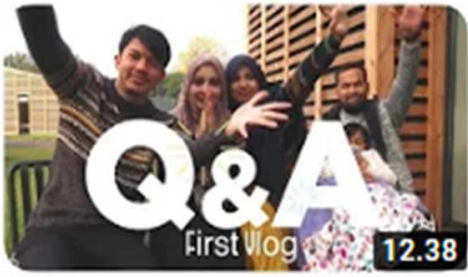

Q N A zaskia shireen irwansyah wisnu ,Baiknya...

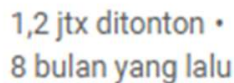

8 bulan yang lalu

Figure 3.2 Videos about Explanation and Q\&A

These two videos are shown to answer questions from the viewers of The Sungkars Family to the guest stars or the content creators themselves about their family life and their religious life. For instance, one of the videos containing a question to Nagita Slavina "Do you want to wear a hijab?". Then Nagita answered "Of course, it is because hijab as one of the obligations of Muslim women and please kindly pray for me to wear hijab soon. Furthermore, the contents of Q\&A also are elaborated to Youtubers or other public figures to attract the viewers' interest. For instance, inviting some public figures who have their own YouTube Channel, such as Ria Ricis, Laudya Cynthia Bella, Prilly Latuconsina, Baim Wong and Paula Verhoeven Wong and others. Also, they invite some popular Islamic figures, such as UstadzUmar Mitra, UstadzAdi Hidayat, Ustadz Abdul Somad, dan Ustadz Khalid Basalamah. Through the contents showed, they deliver something that has been not known yet by other people and it becomes a challenge for them. They feel satisfied when they can convey something that was previously unknown. And they also will be challenged to think outside the box or out of habit as a strategy to attract more viewers to see their videos. 
In terms of the visual quality, The Sungkars Family does not only pay more attention to the quality of the image when filming the videos, but it also maintains the visual quality during the editing process. In the editing process, the editor used a transition technique that can create a better mood of the viewers, for example using certain transition techniques so the movement of the image looks so dynamic. In addition, the views recognized that the use of pictures taken directly is considered clearer than the visualization through graphics. So, all messages will be recorded through speech directly, without the process of dubbing or additional graphics in the filming process. Another thing to be concerned is the audio element, creativity in creating verbal messages informatively and educationally, entertainment that can support the strength of The Sungkars Family Youtube Channel.

\section{B. Islamic Branding through Fashion and Lifestyle}

Nowadays, the trend of the millennial generation has changed drastically and transformed from traditional to the modern trend. Consequently, it influences their lifestyles and fashions as their own identity as a Muslim. Through the YouTube Channel, The Sungkars Family becomes a pioneer in spreading Islamic values through fashion and lifestyle in Indonesia. Also, The Sungkars Familyrepresent themselves as the role models of Muslim in Indonesia through the daily vlogs. Therefore, there are a number of Islamic lifestyle values represented to the public through the uploaded video, such as:

\section{1) Transforming to Wear Hijab}

The term "hijrah" in the Indonesian dictionary can be translated as 'migrating' or 'moving temporarily from one place to a better place for certain reasons such as safety or the pursuit of a better life'. The origin of this term is used to describe the physical migration of the Prophet Muhammad from Mecca to Medina in $622 \mathrm{AD}$ and also the migration of a group of Muslims from Mecca to Abyssinia in 615-622AD [16]. One of the interesting new phenomena is combining the use of social media and Islamic da'wa in Indonesia which have been provided on YouTube channel. Fakhruroji (2015) stated that the popularity of the lifestyle transformation to be a better Muslim arises in millennial Muslim because the social media offers more interactive connection in dissemination of Islamic messages than the other media, such as Short Messaging System (SMS) [17]. The transformation process to be a better Muslim in the social media has changed the way individuals communicate and represent their identities in the social media. So, it becomes one of the popular lifestyles among young Muslim generation in Indonesia. Further on, they argued that the Islamic religion is not only able to help them to be a better human, but it also can create a happiness by combining between lifestyle based on the religious guidance and their activities emphasizing on their tendencies and their hobbies. As the result, there is no any limitation access for millennial youth to learn about Islam.

Among 127 videos uploaded on The Sungkars FamilyYouTube Channel, there are some videos showing the information on the transformation process to be a better Muslim. What is more, the analysis seems to indicate that the public figures invited as the guest starts represented themselves differently from one another, depending on the theme as well as their personality background determined by the content creator. The result of the self-representation on YouTube does not represent their identity in real life. In this case, the guest starts to try to create a new identity on their vlogs about their outfits, hijabs, their communication style, contents, and others. 


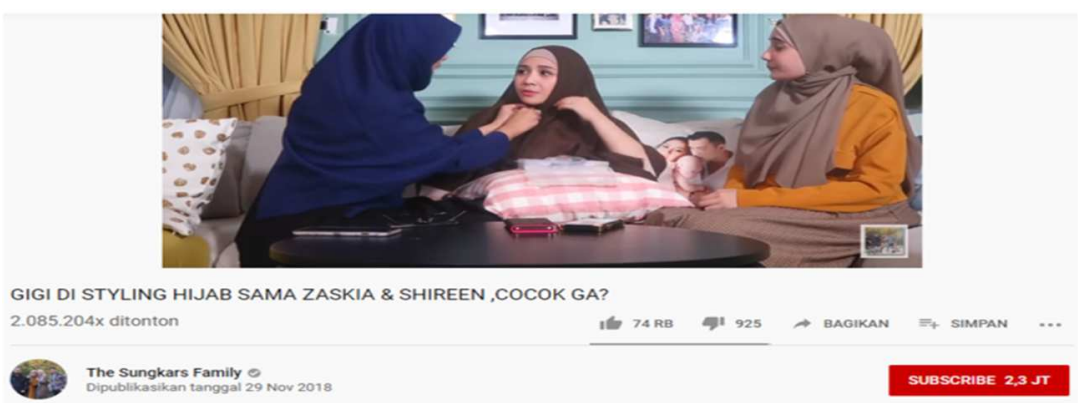

Figure 3.3 A video when Nagita Slavina's wearing hijab [18]

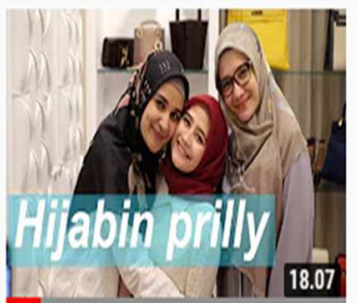

PRILLY LAGI SEDIH?

The Sungkars Family $\bigcirc 1,2$ jtx ditonton 6 bulan yang lalu

This video is about prilly hijub.

Figurre 3.4 A Video when Prilly Ratuconsina's wearing hijab [19].

The examples videos about the transformation process to be a better Muslim are the Vlogs entitled "Gigi distyling hijab samaZaaskia\&SshireenCocokga" (Gigi is styled by Zaskia and Shireen, is she appropriate to wear it?) and "HijabinPrilly, Prillylagisedih?" (Wearing hijab to Prilly, Prilly is sad?). Also, a Vlog with NagitaSlavina as the guest start has been uploaded since November $2^{\text {th, }} 2018$ and has been viewed for about 2,085,204 times. Whereas, the Vlog with PrillyRatuconsina as the guest start has been uploaded since February $24^{\text {th, }} 2019$ and has been watched for about 1.2 million times. In these videos, NagitaSlavinadanPrillyRatuconsina presented themselves as religious Muslim women who were wearing hijab. Then, the admin also carried out a hijab tutorial by choosing colors and models based on the Islamic sharia. Also, both of them praised more beautiful after wearing the hijab and the willingness to wear hijab is their personal desire as a Muslim woman. Based on the author's analysis, the two public figures do framing as a religious woman of Islam in Indonesia who wears hijab. Through the tutorial videos, they use the power of social media to perceive the guest's start in spreading the values of Islam [20].

Furthermore, The Sungkars FamilyYouTube Channel provides the effect of the repetitive representation, such as repeatedly creating vlogs about the Islamic messages by inviting the public figures to wear hijab and offer a hijab tutorial. The content creator would like to build an important framing of how an Islamic woman lives with hijab and how to promote Islam through delivering indirect about Islamic values. By the repetitive media framing, the admin would like to deliver an idea that the guest starts presented in The Sungkars FamilyYouTube Channel are the appropriate public figures as the models of Indonesian Muslim women [20]. In addition, the author identified that The Sungkars Familywants to build the character of their guest stats that NagitaSlavinadanPrillyRatuconsina are emerged to represent the artists who 
are transforming to the better Muslim called by Branston (2003) as the socially representative aspect [20].

\section{2) The Vlog Back Sound covered by Islamic Song}

Based on the conservative interpretations from some people towards the Holy Qur'an and hadith, some Muslims consider music to be a sin and among them completely reject the ideas of music connected to Islam [21]. However, there is a relationship between Islamic sonic practices and musical practices. Even though the diversity of Islam in Indonesia only promotes the popular types of music, such as pop, R\&B, jazz and rock, the influence of Islam has pushed the development of Islamic music. The most common forms of music content are the glorification of the presence of Allah, an invitation to preach in the way of Allah, and praise to the Prophet Muhammad [22].

Nowadays, the music can be such an Islamic style and genre restored the entertainment through the music changes, texts, and the rhythm contextualization. In its history Islamic music in the West produced at least three distinctive categories of popular Islamic music as authentic ethnographic performance of Islamic cultural traditions. One of them is the beat hybrids that combine African-Islamic styles (such as the Gnawa-jazz mix of Hassan Hakmoun; born 1963), even this genre has become popular Islamic music in the global industry. For example, Youssou N'Dour won a Grammy award in Egypt in 2004, a Sufi album (Islamic music) that combined Egyptian, Senegalese and Western music. Moreover, the award was very artistic and promising to the development of the music.

Moreover, the arrangements of western music have been begun to develop and transform into Islamic music by adjusting the musical composition to the singer's voice number and other instruments based on the existed composition without changing the essentials of the music. In this context, The Sungkars FamilyYouTube Channel also popularizes the arrangement of western music to Islamic music. In several vlogs, The Sungkars Familyutilizes the Islamic songs as the back sound to attract the attention of the viewers, such as choosing a song entitled "Guide me Back" by Sided [23].

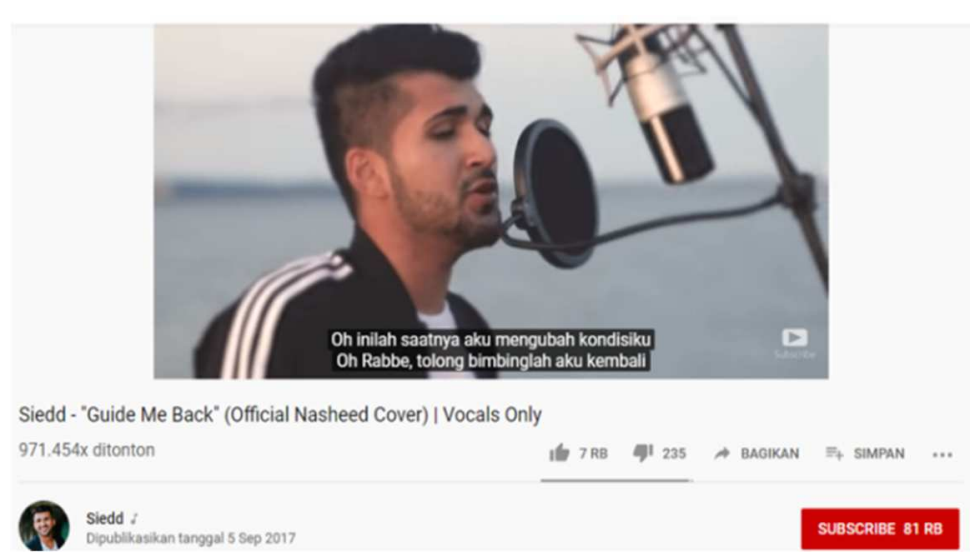

Figure 3.5 Official Islamic Song Covered by Siedd 


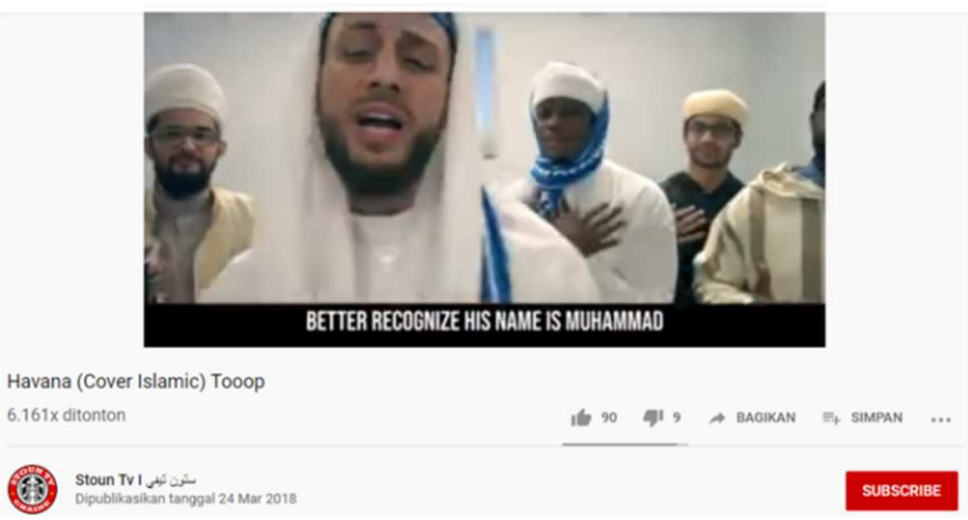

Figure 3.6 Islamic Cover,Havana" to "Madina"

The covered song becomes more interesting to listen because it has been arranged from Shawn Mendes song entitled There's Nothing Holding Me Back. In addition, they choose the covered song from Havana popularized by Camilia Cabello and currently popularized by Stoun TV I YouTube Channel [24]. The use of Islamic songs as the back sound music from the popular western songs cover performed by The Sungkars Family is one of the Islamic brandings through the audio. The admin of The Sungkars FamilyYouTube Channel wants to deliver the Islamic messages through the popular songs. In terms of their objectives, they possess a purpose to use Islamic songs to increase the number of the viewers. It means that it should be balanced to the music containing the Islamic messages. Based on the author analysis, the increasing number of the viewers are occurred when the content creator adds the Islamic songs as the back sound of the Vlog. The Sungkars Family claims to be more satisfied with the responses of the viewers then obtaining many negative comments from the viewers.

\section{3) The Collaboration Video to the Inspiring and Successful YouTuber Muslim}

Besides maintaining the visual and the audio qualities through various contents about the transformation process to be a better Muslim and the Islamic songs, The Sungkars Family also optimizes to achieve their gals in conveying the attractive messages to the active subscribers. Through KanKanchallenge, they try to present an inspiring and successful YouTuber Muslim as the guest star. To be more specific, Variety Magazine (2014) informed that YouTube can be one of the affected children between the ages of 13 to 18 years old [25]. Generally, teenagers are able to find a conclusion from YouTube than celebrities in other media [26]. Although the YouTubers can compare themselves to the other celebrities, there are some interesting aspects that make YouTubes more popular and admired than the Hollywood artists and actors. 


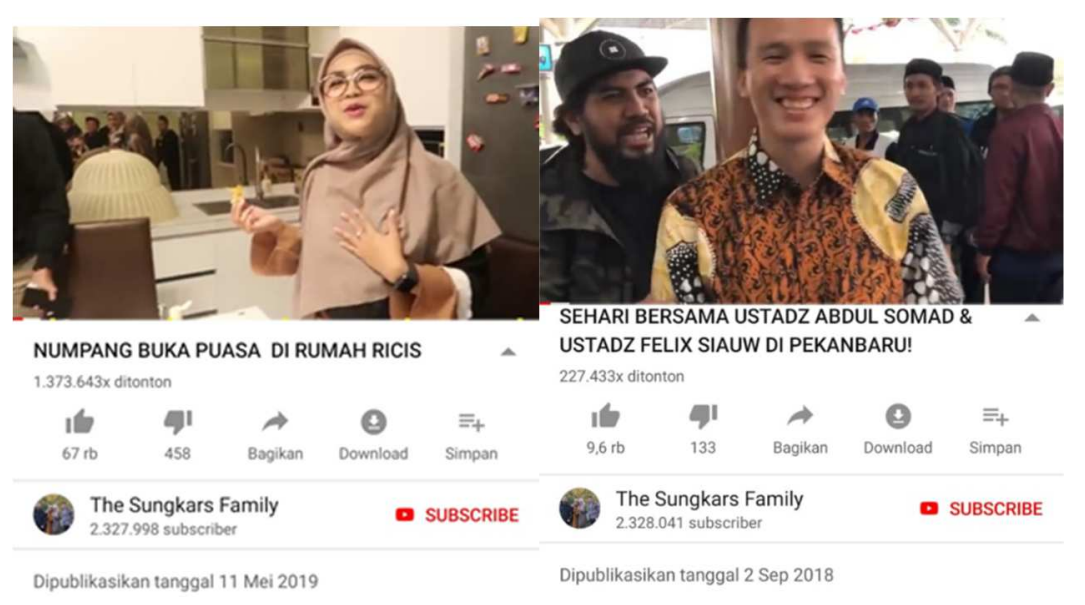

Figure 3.7 The Collaboration Video to the Inspiring and Successful YouTuber Muslim

Therefore, The Sungkar Family collaborates with several YouTubers by displaying content that is in accordance with the current Indonesian Muslim youth reference framework. In addition, another attraction is by collaborating with famous YouTube followers, they try to attract the attention of the audience and provide an opportunity for the audience to easily interact with their idols. Like, the opening of the Q\&A for YouTuber to his fans through social media and YouTube comment column. Based on the author's analysis, from the collaborative vlogs presented, the theme of the message delivered is a religious social campaign in the form of missionary messages for young people who are emigrating, this is also integrated with information about culinary, tutorials, and business information. So, the average audience is Muslim teenagers get inspiration from vloggers whom they consider to be successful, in the vlog production that is The Sunggars Family. In producing this collaborative vlog, they prepared very well, starting from the initial idea of the theme of the Da'wa safari, and KanKan Challenge, writing scripts by including question or Q\&A content from guest star fans, as well as taking pictures and visual editing in accordance with preferences their YouTube Channel subscriber.

\section{Conclusion}

The Sungkars Family becomes one of the pioneers in delivering Islamic values through their fashion and lifestyle. By providing sharing videos and daily Vlog, The Sungkars Family has represented as the role model of the YouTube channel for the Muslims in Indonesia. Further on, there are Islamic lifestyle values in their vlogs that are represented to the public, namely the hijrah with the hijab, entertainment using Islamic music, and the famous Muslim Youtuber as the inspirator of life.

\section{References.}

[1] R. C. Alvara, "The Urban Middle-class Millennials Indonesia: Financial and Online Behavior and Heriyanto, D.Indonesian Youths Say Religion Key to Happines," 2017. .

[2] Internetworldstats, "world rankings of the social media use." .

[3] T. Rahman, "Hijrah and the Articulation of Islamic Identity of Indonesian Millenials Using Instagram," in Research Report for Visiting Professor Program, 2018, p. 3.

[4] P. Media Impact, Understanding Media Metrics: Youtube Basic for Journalists. USC Annenberg Norman Lear Centre. 
[5] Journalism, "www.journalism.org," 2014. .

[6] E. Fisher, "How less alienation creates more exploitation? Audience labour on social network sites, Triple C: Communication, capitalism and critique," vol. 10, no. 2. pp. 171-183, 2012.

[7] D. McQuail, Teori Komunikasi Massa, Volume1. Jakarta: Salemba Humanika, 2011.

[8] M. Castells, "Communication, power and counter- power in the network society," Int. J. Commun., vol. 1, no. 2, p. 2007, 2017.

[9] APJII, "Survei Internet," 2016. .

[10] "Muhtifah, Lailial, and RickaTesiMuskania. 2018. The Design on Quality System Model of FTIK IAIN Pontianak in SNPT 2015 and QMS ISO 9001:2015. Jurnal Pendidikan Islam7(2): 383-404. https://doi.org/10.14421/jpi.2018.72.383-404."

[11] R. Gehl, "YouTube as archive Who will curate this digital Wunderkammer?," Int. J. Cult. Stud., vol. 12, no. 1, pp. 43-60, 2009.

[12] Anang Sujoko dan Megasari N. Fatanti, "Let's Start Your Own Vlog Promoting Indonesian Digital Entrepreneur Using Youtube Chanel," J. Appl. Manag., vol. 15, no. 4, pp. 579-584.

[13] C. Hine, Virtual ethnography. London: Sage Publications, 2000.

[14] D. Machin, Ethnographic Research for Media Studies. London: Arnold, 2002.

[15] The Sungkar Family, "Q n A Zaskia shireen irwansyah wisnu, baiknya...," 2018.

[16] K. Masud, F. E. Dale, and P. James, "The obligation to migrate: The doctrine of hijra in Islamic law," in Muslim Travellers: Pilgrimage, Migration, and the Religious Imagination, London: Routledge, 1990.

[17] M. Fakhruroji, "Mediatization of religion in 'texting culture': self-help religion and the shifting of religious authority," Indones. J. Islam Muslim Soc., vol. 5, no. 2, pp. 231-254, 2015.

[18] The Sungkar Family, "Gigi di styling hijab sama zaskia \& shireen, cocok ga?," 2018. .

[19] The Sungkar Family, "Prilly Lagi Sedih?," 2019. .

[20] Gill Branston and R. Stafford, The Media Student's Book, 3rd ed. New York and London: Routledg, 2003.

[21] Akin Euba, "Yoruba Drumming:The Du'ndu'n Tradition," in Bayreuth African Studies, Germany: Bayreuth University, 1990.

[22] Veit Erlmann, Music and the Islamic Reform in the Early Sokoto Empire: Sources, Ideology, Effects. Marburg. Stuttgart: Deutsche Morgenländische Gesellschaft, 1986.

[23] Siedd, "Siedd"Guide me back" (Official nasheed cover)! vocals only," 2017. .

[24] Stoun TV I, "Havana (cover islamic) tooop," 2018. .

[25] Variety, "Survey: YouTube Stars More Popular Than Mainstream Celebs Among U.S. Teens," 2014. .

[26] Defy Media, Acumen report: Youth Video Diet. 2015. 